\title{
Autoimmune polyendocrine failure - Type 1 (insulin-dependent) diabetes mellitus and hypothyroidism - after allogeneic bone marrow transplantation in a patient with lymphoblastic leukaemia
}

\author{
B. Vialettes ${ }^{1}$, D.Maraninchi ${ }^{2}$, M.P.San Marco $^{3}$, F.Birg ${ }^{4}$, A.M.Stoppa ${ }^{2}$, C.Mattei-Zevaco ${ }^{1}$, C. Thivolet ${ }^{5}$, L.Hermitte ${ }^{1}$, \\ P. Vague ${ }^{1}$, P. Mercier ${ }^{6}$ \\ ${ }^{1}$ Department of Diabetology, University of Marseille, France \\ ${ }^{2}$ Medical Oncology Unit, Paoli Calmettes Institute, Marseille, France \\ ${ }^{3}$ Laboratory of Immunology, University of Marseille, France \\ ${ }^{4}$ INSERM U 119 Marseille, France \\ ${ }^{5}$ INSERM U 197, Lyon, France \\ ${ }^{6}$ France Transplant Unit, Marseille, France
}

Summary. In this report we describe a patient who, after allogeneic bone marrow transplantation from her HLA-identical sister, developed polyendocrine failure in the form of Type 1 (insulin-dependent) diabetes mellitus and hypothyroidism. This was the result of the transfer of donor lymphoid cells which were activated by allogeneic bone marrow transplantation. The full chimerism of the recipient was demonstrated by restriction fragment length polymorphism analysis from nucleated blood cells and fibroblast DNA. During the 9-year follow-up, the donor developed hypothyroidism and signs of pre-Type 1 diabetes. This clinical observation resembles the adoptive transfer of diabetes observed in non-obesediabetic mice and $\mathrm{BB}$ rats and confirms the role of immune processes in the pathogenesis of this disease.

Key words: Type 1 (insulin-dependent) diabetes mellitus, graft versus host disease, allogeneic bone marrow transplantation, hypothyroidism, autoimmunity.
Type 1 (insulin-dependent) diabetes mellitus and hypothyroidism are recognised as organ specific autoimmune diseases occurring in genetically predisposed subjects after exposure to one or more environmental factors $[1,2]$. The sequence of events which leads to the final destruction of pancreatic beta cells and thyrocytes remains poorly understood. In this report, we describe a patient who, after allogeneic bone marrow transplantation (BMT) for acute lymphoblastic leukaemia, developed an autoimmune reaction which led to polyendocrine failure. This was the result of transfer of donor lymphoid cells which were activated by the allogeneic BMT. The full chimerism of the lymphoid system of the recipient was confirmed by DNA polymorphismanalysis. Inaddition, the donor later developed autoimmune hypothyroidism and signs of pre-Type 1 diabetes. This is the first report of an adoptive transfer of Type 1 diabetes and hypothyroidism in a human subject. This model may enhance our understanding of the pathogenesis of these autoimmune diseases.

\section{Case report (Fig. 1)}

The female patient was 13 years old when the diagnosis of acute lymphoblastic leukaemia was made in 1979. Blast cells were phenotypically CALLA (common acute lymphoblastic leukemia antigen) positive, and at the time of diagnosis, there was no visceral involvement or hyper- leucocytosis. She went into complete remission after vincristine, prednisone and L-asparaginase treatment. She then received cranial irradiation ( 2400 rads) and intrathecal therapy with 6-mercaptopurine and methotrexate. Subsequently, she had five episodes of central nervous system relapse between June 1980 and December 1981 treated by both intra-thecal and intensive systemic chemotherapy. During this period, she was considered for an allogeneic BMT from her HLA-identical lymphoblastic leukaemia-cell negative sister. HLA phenotypes of the family were as follows: father: haplotype $\mathrm{a}=\mathrm{Aw} 32 ; \mathrm{B} 37$; DR-; haplotype $\mathrm{b}=\mathrm{A} 9 \mathrm{~W} 23$; BW 51; DR4. Mother: haplotype c=A1; B8; DR 3; haplotype d = AW 33; B 27; DR-. DR-meant serologically undefined. The results of mixed lymphocyte culture confirmed serological data and excluded a parental homozygosity of the HLA D region. The patient was identical to her sister with the phenotype a/c; her brother, diagnosed with Type 1 diabetes in 1975, had an HLA phenotype of a/r ( $\mathrm{r}$ for recombination between B and DR: A 33, B 27, DR 3). Therefore, in comparison to both donor and recipient, he was haploidentical for HLA class I $\left(\mathrm{a} / \mathrm{d}^{\prime}\right)$ but genoidentical for HLA class II $\left(\mathrm{a} / \mathrm{c}^{\prime \prime}\right)$. Another brother who was in good health had phenotype b/d. The mother had been previously treated for Graves' disease. There was no other history of diabetes in the family.

The patient and her sister were $\mathrm{ABO}$ incompatible (types $A$ and 0 , respectively). Before grafting, the patient 


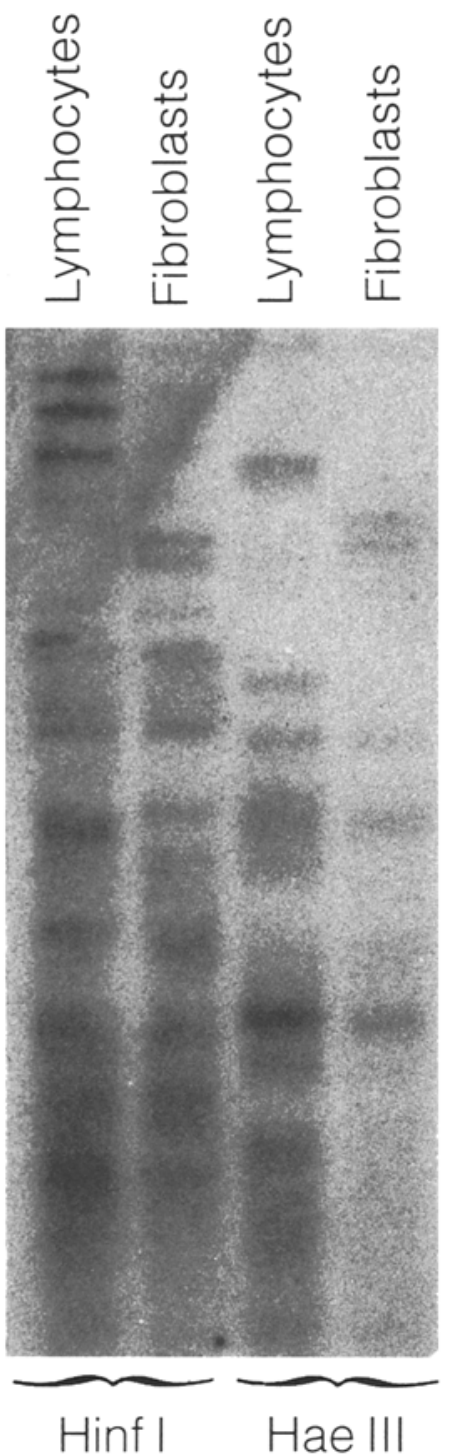

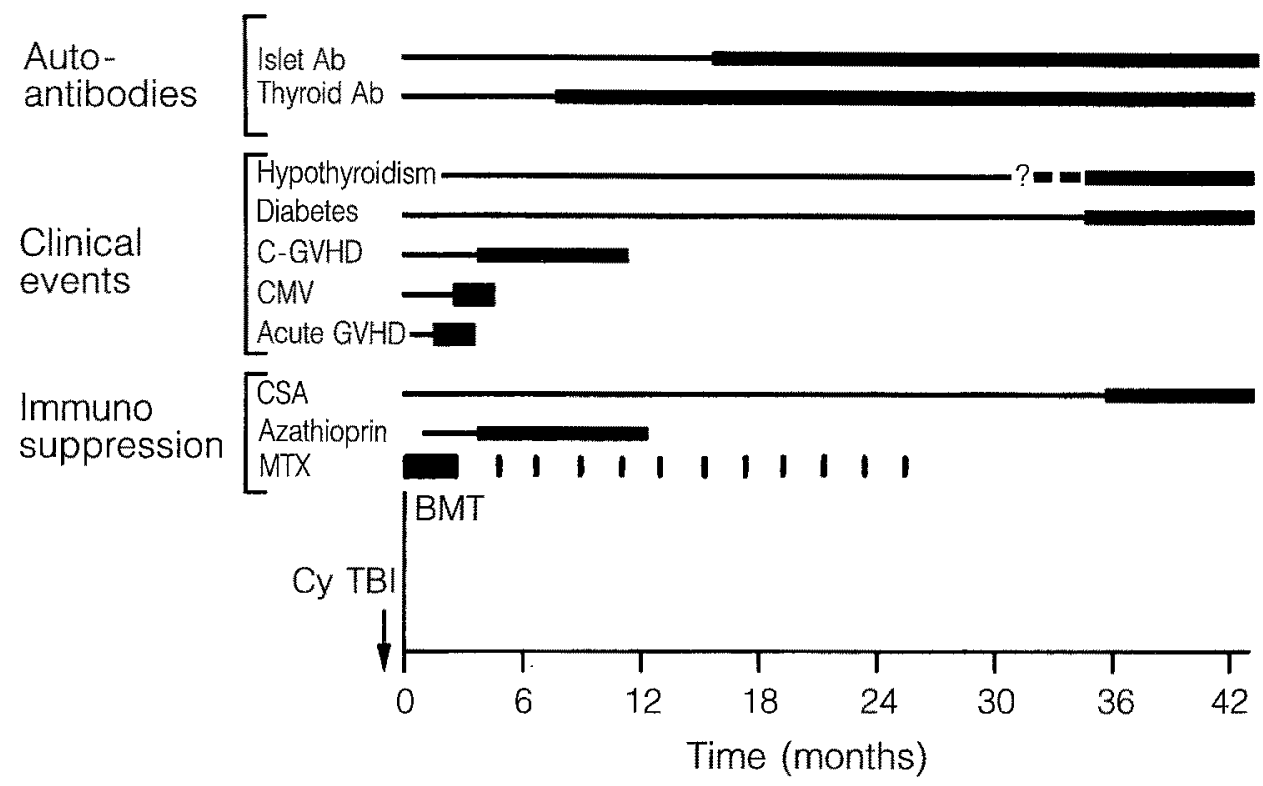

Fig. 1. Summary diagram of the case report. Ab, Antibodies; GVHD, graft vs host disease (acute and chronic GVHD); CMV, cytomegalovirus; CSA, cyclosporin A; MTX, methotrexate; Cy, cyclophosphamide; TBI, total body irradiation: $\mathrm{BMT}$, bone marrow transplantation quired insulin therapy and in view of positive anti-islet cell antibodies (ICA), she was started 38 months post-transplant on cyclosporin $\mathrm{A}\left(5 \mathrm{mg} \cdot \mathrm{kg}^{-1} \cdot \mathrm{day}^{-1}\right.$ orally). L-thyroxine was also started for hypothyroidism. After 6 months of cyclosporin therapy no improvement of the diabetes was noted and immunosuppressive treatment was discontinued.

The patient is still alive 9 years after transplantation and receiving insulin, L-thyroxine and percutaneous oestrogen supplementation for secondary hypogonadism.

\section{Restriction fragment length polymorphism analysis}

Restriction fragment length polymorphism was used to detect engraftment and chimerism in the recipient after BMT $[4,5]$. As a blood sample from the donor was not available, the restriction enzyme patterns of DNAs prepared from the patient's blood and skin fibroblasts were compared. Minisatellite DNA probe 15.1.11.4 (a 600 base pair fragment, cloned in an M13 vector), obtained from Dr. A.J.Jeffreys (University of Leicester, Leicester, UK) was used, as it can detect many highly variable loci simultaneously $[6,7]$. Single-stranded DNA was prepared and labelled in vitro as described previously [6].

Ten $\mu g$ aliquots of either blood or fibroblast DNA were digested with either Hinf I or Hae III using the conditions recommended by the manufacturer, submitted to agarose gel electrophoresis, transferred to nitrocellulose, and hybridized with $1 \times 10^{6} \mathrm{cpm} / \mathrm{ml}$ of denatured probe as described previously [8]. Blots were exposed to Kodak XAR 5 films at $-80^{\circ} \mathrm{C}$ using intensifying screens.

Figure 2 clearly demonstrates that different sets of labelled fragments were obtained in DNA isolated from nucleated blood cells and skin fibroblasts, indicating that the patient is a chimera. 
Table 1. Autoantibodies at follow-up in the patient studied (titre in inverse dilution)

\begin{tabular}{|c|c|c|c|c|c|c|c|c|}
\hline & $\begin{array}{l}\text { Follow-up } \\
\text { (months } \\
\text { post BMT) }\end{array}$ & $\begin{array}{l}\text { Anti-islet } \\
\text { cell Ab } \\
\text { (JDF units) }\end{array}$ & $\begin{array}{l}\text { Anti-thyroid } \\
\text { Ab anti-micro- } \\
\text { somal/anti- } \\
\text { thyroglobulin }\end{array}$ & $\begin{array}{l}\text { Anti-parietal } \\
\text { gastric } \mathrm{Ab}\end{array}$ & $\begin{array}{l}\text { Anti-smooth } \\
\text { muscle/anti- } \\
\text { mitochondrial } \\
\mathrm{Ab}\end{array}$ & $\begin{array}{l}\text { Anti-acethyl- } \\
\text { choline } \\
\text { receptor } \mathrm{Ab} \\
\text { (nmol/1) }\end{array}$ & $\begin{array}{l}\text { Anti-interstitial } \\
\text { substance } \mathrm{Ab}\end{array}$ & $\begin{array}{l}\text { Clinical } \\
\text { events }\end{array}$ \\
\hline Pre-BMT & $\begin{array}{l}\text { Donor } \\
\text { Recipient }\end{array}$ & $\begin{array}{l}0 \\
0\end{array}$ & $\begin{array}{c}1600 / 2560 \\
0 / 0\end{array}$ & $\begin{array}{r}0 \\
100\end{array}$ & $\begin{array}{c}0 / 0 \\
10 / 100\end{array}$ & $\begin{array}{l}0 \\
3.5\end{array}$ & $\begin{array}{r}0 \\
1001\end{array}$ & \\
\hline Post-BMT & $\begin{array}{l}1 \\
2\end{array}$ & $\begin{array}{l}0 \\
0\end{array}$ & $\begin{array}{l}0 / 0 \\
0 / 0\end{array}$ & $\begin{array}{r}50 \\
10 / 50\end{array}$ & $\begin{array}{l}10 / 50 \\
10 / 50\end{array}$ & $\begin{array}{l}2 \\
2\end{array}$ & $\begin{array}{l}100 \\
100\end{array}$ & $\begin{array}{l}\text { Acute } \\
\text { GVHD gde1 } \\
\text { and CMV in- } \\
\text { fection Chro- } \\
\text { nic GVHD }\end{array}$ \\
\hline & 7 & 0 & $0 / 1280$ & 50 & $50 / 0$ & 3 & 0 & \\
\hline & 8 & 0 & $1600 / 163840$ & 50 & $100 / 0$ & 2 & 0 & Azathioprin \\
\hline & 9 & 0 & $1600 / 163480$ & 50 & $100 / 0$ & 2.5 & 0 & $(+5$ to +12 \\
\hline & 10 & 0 & $1600 / 20480$ & 50 & $100 / 0$ & 1.6 & 0 & months) \\
\hline & 15 & $>80$ & $400 / 2560$ & 50 & $10 / 0$ & 1.3 & 0 & \\
\hline & 18 & $>80$ & $400 / 1280$ & 50 & $10 / 0$ & 3 & 0 & \\
\hline & 21 & $>80$ & $400 / 1280$ & 10 & $10 / 0$ & 3.7 & 0 & \\
\hline & 24 & $>80$ & $400 / 1280$ & 10 & $10 / 0$ & 3.4 & 0 & \\
\hline & 30 & $>80$ & - & - & - & - & - & Hypothyroid- \\
\hline & 36 & $>80$ & - & - & - & - & - & ism and \\
\hline & 39 & $>80$ & $400 / 640$ & 10 & $10 / 0$ & 3 & 0 & diabetes \\
\hline
\end{tabular}

Ab, Antibodies; GVHD, graft vs host disease; CMV, cytomegalovirus; BMT, bone marrow transplantation; JDF, Juvenile Diabetes Foundation

\section{Serological methods and functional endocrine investigations}

Serum samples from the patient and her sister were collected before and post-transplantation at regular intervals. Aliquots were kept frozen at $-80^{\circ} \mathrm{C}$ and subsequently used for antibody $(\mathrm{Ab})$ screening [9]. Anti-ICA were detected by conventional indirect immunofluorescence on frozen sections of human pancreas. Our laboratory has participated in the ICA Proficiency Programmes with the following result: sensitivity 81 and $100 \%$; specificity 95 and $100 \%$; consistency 90 and $95 \%$. Anti-glutamic acid decarboxylase (GAD) Ab were detected by an immunotrapping enzyme activity assay as described previously [10]. Results were expressed in arbitrary units as the percentage of the GAD activity trapped by a positive reference control. The positivity threshold was 0.11 units. Unfortunately GAD Ab levels could only be determined in the donor.

Thyroid microsomal and thyroglobulin $\mathrm{Ab}$ were estimated by tanned erythrocyte haemagglutination using the microsome and thyroid test kits (Wellcome Diagnostics, Dartford, Kent, UK). Titers of 1:100 and 1:40 respectively, were considered positive.

Determination of acetylcholine receptor $\mathrm{Ab}$ was performed as described by San Marco et al. [9]. Several normal human sera were used as controls to exclude non-specific background labelling. The Ab titre was expressed as nmoles of ${ }^{125} \mathrm{I}$ alpha bungarotoxin binding sites. Negative titres were defined as $0.5 \mathrm{nmol} / 1$ and limit titres ranged from 0.5 to $1.0 \mathrm{nmol} / \mathrm{l}$.

Several other anti-organ $\mathrm{Ab}$ were investigated as reported by San Marco et al. [9]. $\mathrm{T}_{3}, \mathrm{~T}_{4}$ and thyroid stimulating hormone (TSH) levels were measured using conventional radioimmunoassay. Acute insulin response to i.v. glucose was evaluated by summation of plasma insulin values 2 and $5 \mathrm{~min}$ after the end of the i.v. glucose load $(0.3 \mathrm{~g} / \mathrm{kg}$ injected in $2 \mathrm{~min})$ as previously described [11].

\section{Autoantibody follow-up and clinical function of target organs in recipient}

Serial frozen serum samples available prior to and following BMT were investigated with a series of anti-organ Ab. Results are summarized in Table 1. Development of the various autoantibodies did not occur in parallel. Anti-cytoplasmic ICA became detectable only 15 months after grafting and were of the IgG type (IgG-ICA). No antiICA of the IgM type were detectable in any serum sample. IgG-ICA remained positive at a high titre during the 21 months preceding the clinical onset of the diabetes, and persisted despite cyclosporin A therapy.

High titre of anti-thyroid $\mathrm{Ab}$ appeared 7 months after the graft. The kinetics of anti-thyroglobulin and antimicrosomal Ab were identical, but the titre of anti-thyroglobulin $\mathrm{Ab}$ was always much higher. There was a progressive decline of the titres between 8 and 39 months. Subclinical hypothyroidism was diagnosed based on the low value of $T_{3}(0.9 \mathrm{ng} / \mathrm{ml})$ and $T_{4}(0.9 \mathrm{ng} / \mathrm{ml})$ and only a weak rise in TSH, which could be explained by previous cranial irradiation.

Anti-parietal gastric cells, anti-acetylcholine receptor and anti-smooth muscle $\mathrm{Ab}$ were consistently detected both during the follow-up, and prior to transplantation. No clinical signs of myasthenia gravis were observed, however, the Ab titres remained present but low. Ab directed against the inter-cellular substance of stratified epithelium and mitochondrial antigens were positive be- 


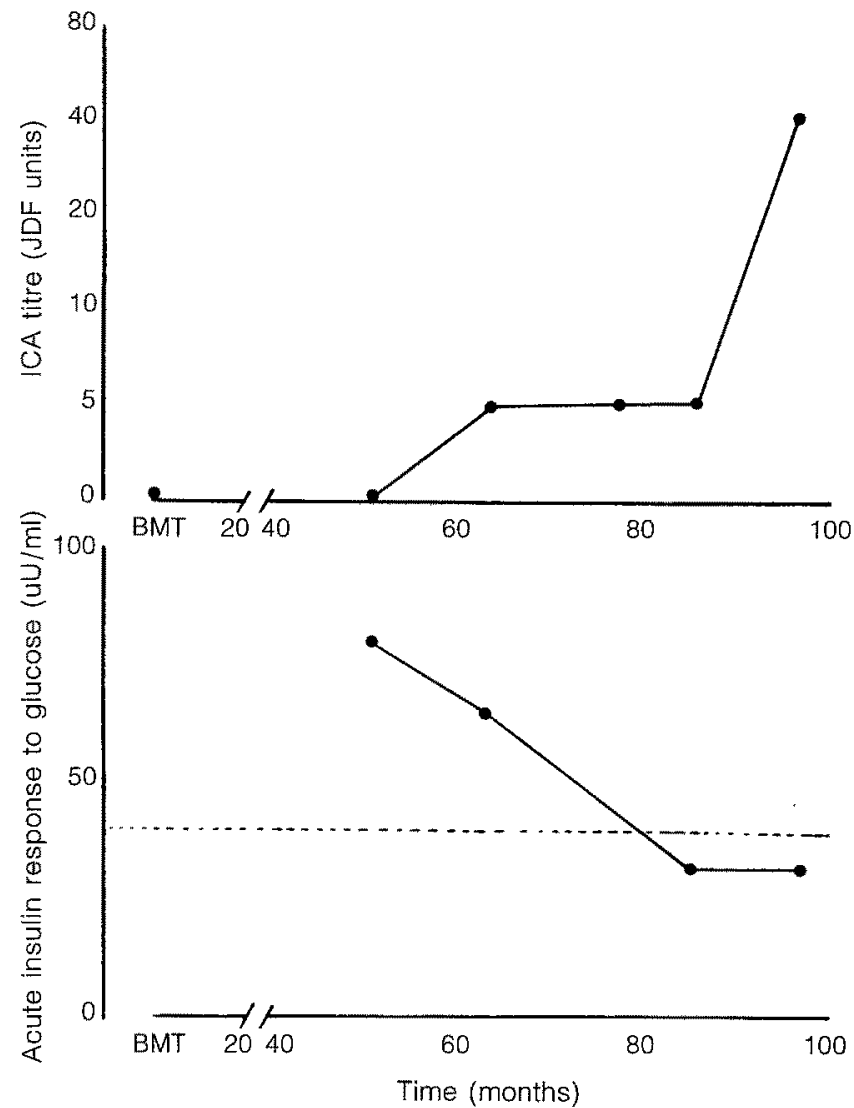

Fig. 3. Progression of islet cell antibody (ICA) titre (expressed in Juvenile Diabetes Foundation units) and acute insulin response to i.v. glucose in the donor after the bone marrow transplant (BMT) from her sister (. . . represents the lower limit of the 5 th percentile of the normal population [11])

fore grafting, for 2 months post-transplantation and thereafter disappeared. Anti-nuclear $\mathrm{Ab}$ were not detected.

\section{Follow-up of the donor}

The donor was unavailable for testing until 52 months after BMT (16 months after the onset of diabetes in the sister). At this time her fasting plasma glucose was normal $(5.5 \mathrm{~mol} / \mathrm{l})$. ICA were undetectable. Anti GAD Ab were positive (0.355 units). Acute insulin response to glucose was in the normal range (Fig.3). Anti-thyroid $\mathrm{Ab}$ were positive (anti-thyroglobulin 1/20480 and anti-microsomal $\mathrm{Ab} 1 / 6400$ ) and thyroid failure was characterized by a significant rise of TSH level $(11 \mathrm{mU} / 1$, normal range $0.25-$ $3.5 \mathrm{mU} / 1)$ with normal free $T_{3}$ and free $T_{4}$ levels. Other auto-antibodies were found to be negative (smooth muscle, gastric parietal, adrenal cells $\mathrm{Ab}$, acetylcholine receptor $\mathrm{Ab}$ and mitochondria $\mathrm{Ab}$ ). The donor was subsequently treated by L-thyroxine and submitted to a serial evaluation of markers of pre-Type 1 diabetes namely, ICA and GAD Ab measurement and evaluation of acute insulin response to i. $v$. glucose load. The follow-up of these markers is represented in Figure 2. There was a progressive increase of ICA titre. Meanwhile a concomitant decrease of the acute insulin response occurred. In addition anti GAD Ab were permanently positive throughout the follow-up (1987: 0.355, 1988: 0.581, 1989: 0.396, 1990: 0.410 and 1991: 2.92 units). She still has normal fasting plasma glucose, despite a high titre of ICA, presence of $\mathrm{GAD} \mathrm{Ab}$ and low acute insulin response to glucose.

\section{Discussion}

This unique report of autoimmune polyendocrine failure with combined Type 1 diabetes and hypothyroidism after allogeneic BMT is strikingly suggestive of an adoptive transfer of the disease by the transplantation of immunocompetent cells from the donor. The full haematopoietic chimerism of the recipient after BMT was documented by the erythropoietic chimerism for $\mathrm{ABO}$ markers and comparative analysis of fibroblast and lymphocyte DNA. Thus, it is likely that the production of anti-ICA and antithyroid $\mathrm{Ab}$, and the destruction of the target cells in both pancreas and thyroid are due to lymphoid cells from the donor. In this context, the pathogenesis of the autoimmune disease may be due to either an active autoimmune phenomenon, as a part of the immune disorders associated with the GVHD [12], or to a transfer of a subclinical autoimmune disease of the donor, activated to a clinical level by BMT $[12,13]$. Most likely GVHD does not play a role in the pathogenesis of endocrine failure. Occurrence of autoantibodies has been described after allogeneic $\mathrm{BMT}$, but anti-thyroid $\mathrm{Ab}$ and Anti-ICA are rare in comparison to other autoantibodies $[9,14,15]$. In animal studies, GVHD following BMT in semi-allogeneic F1 mice is associated with pathological evidence of severe lymphocytic infiltration of islets of Langerhans [16]. But in this model, glucose tolerance remained normal. Such observations have not been made in dogs or humans, where the rare pancreatic lesions which can be observed after BMT, involve either exocrine pancreas or pancreatic and biliary ducts [17]. In this case report it is important to remember that anti-ICA were undetectable for the entire period where GVH reactions were observed in the patient. Humoral anti-pancreatic reaction became obvious when GVHD disappeared, after discontinuation of the post-graft immunosuppressive therapy. Thus, the hypothesis of an adoptive transfer of two organ specific autoimmune diseases is plausible.

Similarly, other cases of transfer of diseases related to autoimmunity during BMT have been reported in the literature, including myasthenia gravis [18-22] and autoimmune thrombocytopoenic purpura $[13,23]$. In one patient hypoglycaemia was induced by the transfer of anti-insulin receptor $\mathrm{Ab}$ [24]. Adoptive transfer of autoimmune thyroiditis has been previously reported by Wyatt et al. [25] and Aldouri et al. [26]. Adoptive transfer of hypothyroidism, seems likely in our patient as the donor was antibody positive and rapidly developed subclinical hypothyroidism. The situation is different for diabetes at the time of the BMT. One can speculate that anti-pancreatic clones of the donor were quiescent and activated by BMT in the recipient. In animal models, adoptive transfer of diabetes by splenocytes [27, 28] and bone marrow cells [29] has been 
reported. In $\mathrm{BB}$ rats previous in vitro activation of splenocytes is required [27]. In non-obese-diabetic mice the recipient has to be irradiated before reconstitution [28, 29]. Adoptive transfer of both diabetes and thyroiditis has been described in a model in which the BB rat is donor and the athymic rat, recipient [30]. The follow-up of the donor in our study confirmed the presence of these resting autoreactive clones directed against islet beta cells. AntiGAD Ab and a high titre of ICA became detectable several months later and a progressive loss of acute insulin response to i. v. glucose was observed. The combination of these pre-diabetes markers has been shown to have a good predictive value in family studies $[10,11,30-32]$. Therefore, the donor can be considered to be at a high risk for the development of Type 1 diabetes.

In the recipient the evolution could have been accelerated by BMT-induced activation of lymphocytes. Indeed BMT with or without GVHD complications, is a situation where post-graft lymphocyte activation has been demonstrated, and leads either to a T-lymphocyte population imbalance or to a polyclonal activation [33-35]. As seen in animal models, our patient exhibited both requisite conditions for diabetes transfer i.e. activation of donor cells, irradiation of recipient.

The HLA identity at the D locus with the pre-diabetic donor and the diabetic brother conferred to the patient a high susceptibility to Type 1 diabetes. According to Tarn et al. [36] her cumulative risk of becoming insulin-dependent by age 25 could be estimated at $16 \%$. But in addition, the HLA identity between donor and recipient probably also played an important role in allowing the general mechanisms of MHC-restricted T lymphocytoxicity. This observation represents a mirror image of the observations of Sibley et al. [37]. These authors showed that endocrine parts of the pancreatic graft from a non-diabetic twin or HLA identical sibling were destroyed by the diabetic twin with a re-onset of the causal autoimmune disorder. In our case report, the diabetes seems to occur after exposition of the target cells to immunocompetent cells which are MHC-compatible. In the case reports of Sibley et al. [37], the time-lag between the transplantation and the recurrence of diabetes was shorter than in ours ( 2 to 3 months) and the recurrence of ICA was found in only two out of four subjects [37].

In conclusion, one can conceive that the following sequence of events occurred after BMT in our patient: firstly, activation in a susceptible genetic background of both weakly active (anti-thyroid) and quiescent (anti-ICA) clones of T lymphocytes; secondly, facilitation of the cytotoxic process by the MHC identity between the donor lymphocytes and the recipient target cells; thirdly, polyglandular failure by destruction of both endocrine cells. This clinical observation, very similar to adoptive transfer of autoimmune diabetes in animal models, confirms the contribution of the immune system to the pathogenesis of Type 1 diabetes.

Acknowledgements. We thank the laboratory staff of Dr. J.F.Mattei for initiating a culture of fibroblasts from a skin biopsy of the patient. We thank Dr. A.J.Jeffreys (University of Leicester, Leicester, UK) for the minisatellite probe. We are also indebted to Dr. C.Mawas
(INSERM U 119, Marseille, France) and Dr. D.E.R. Sutherland (University of Minnesota, Minneapolis, Minn., USA) for their valuable suggestions and discussions during the preparation of the manuscript. This work was supported in part by grants from the Caisse $\mathrm{Na}-$ tionale d'Assurance Maladie des Travailleurs Salariés.

\section{References}

1. Eisenbarth GS (1986) Type 1 diabetes mellitus - a chronic autoimmune disease. N Engl J Med 314:1360-1368

2. Utiger RD (1991) The pathogenesis of autoimmune thyroid disease. New Engl J Med 325: 278-279

3. Thomas ED, Storb R, Clift RA et al. (1975) Bone marrow transplantation. NEngl J Med 292: 832-843, 895-902

4. Blazar BR, Orr HT, Arthur DC, Kersey JH, Filipovotch AH (1985) Restriction fragment length polymorphisms as markers of engraftment in allogeneic marrow transplantation. Blood 66: $1436-1444$

5. Knowlton RG, Brown VA, Braman JC et al. (1986) Use of highly polymorphic DNA probes for genotypic analysis following bone marrow transplantation. Blood 68: 378-385

6. Jeffreys AJ, Wilson V, Thein SL (1985) Hypervariable "minisatellite" regions in human DNA. Nature 314:67-73

7. Jeffreys AJ, Wilson V, Thein SL (1985) Individual-specific "fingerprints" of human DNA. Nature 316:76-79

8. Xerri L, Maraninchi D, Bertheas MF, Gaspard MH, Mawas C, Birg F (1989) "Minisatellite" DNA probes detect engraftment and/or chimerism in recipients of HLA-matched bone marrow transplants. Transpl Int 2: 53-55

9. San Marco M, Vialettes B, Maraninchi D, Bernard D (1991) Autoantibody formation after bone marrow transplantation: a comparison between autologous and allogeneic grafts. Autoimmunity 11:7-12

10. Thivolet C, Tappaz N, Durand A et al. (1992) Glutamic acid decarboxylase (GAD) auto-antibodies are additional predictive markers of type 1 (insulin-dependent) diabetes mellitus in high risk individuals. Diabetologia 35: $570-576$

11. Vialettes B, Mattei-Zevaco C, Badier C, Ramahandridona $G$, Lassmann-Vague V, Vague $\mathrm{Ph}$ (1988) Low acute insulin response to intravenous glucose. A sensitive but non specific marker of early stages of type 1 diabetes. Diabetologia 31:592-596

12. Atkinson K (1990) Chronic graft versus host disease. Bone Marrow Transplant 5: 69-82

13. Marmont AM (1992) Autoimmunity and allogeneic bone marrow transplantation. Bone Marrow Transplant 9: 1-3

14. Rouquette-Gally AM, Boyeldieu D, Prost AG, Gluckman E (1988) Autoimmunity after allogeneic bone marrow transplantation. A study of 53 long-term-surviving patients. Transplantation 46: $238-240$

15. Holmes JA, Livesey SJ, Bedwell AE, Amos N, Whittaker JA (1989) Auto-antibody analysis in chronic graft-versus-host-disease. Bone Marrow Transplant 4:529-531

16. Kolb H, Freytag G, Kiesel V, Kolb-Bachofen V (1981) Cellular immune reactions against pancreatic islets as a consequence of graft versus host disease. Clin Exp Immunol 43:121-125

17. Sale GE, Shulman HM (1984) Pathology of other organ systems. In: Sale GE, Shulman HM (eds) Pathology of bone marrow transplantation. Masson Publishing USA, Inc, New York, pp 190-198

18. Smith CI, Aarli JA, Biberfeld P et al. (1983) Myasthenia gravis after bone marrow transplantation. Evidence for a donor origin. N Engl J Med 309: 1565-1568

19. Bolger GB, Sullivan KM, Spence AH et al. (1986) Myasthenia gravis after allogeneic bone marrow transplantation: relationship to chronic graft versus host disease. Neurol 36: 1087-1091

20. Lefvert A, Björkholm M (1987) Antibodies against the acetylcholine receptor in hematologic disorders: implication for the development of myasthenia gravis after bone marrow transplantation. New Engl J Med 317: 170 (Letter) 
21. Grau JM, Casademont J, Montforte R (1990) Myasthenia gravis after bone marrow transplantation; report of a new case and pathogenic considerations. Bone Marrow Transplant 5: 435-437

22. Melms A, Faul C, Sommer N, Wiethölter $H$, Müller CA, Ehninger G (1989) Myasthenia gravis after BMT: identification of patients at risk? Bone Marrow Transplant 9: 78-79

23. Anasetti C, Rybka W, Sullivan KM, Banaji M, Slichter SJ (1989) Graft-v-host disease is associated with autoimmune-like thrombocytemia. Blood 73: 1054-1058

24. Rochet N, Blanche S, Carel JC et al. (1989) Hypoglycaemia induced by antibodies to insulin receptor following a bone marrow transplantation in an immunodeficient child. Diabetologia 32: $167-172$

25. Wyatt DT, Lum L, Caper J, Hunter J, Camitta B (1990) Autoimmune thyroiditis after bone marrow transplantation. Bone Marrow Transplant 5:357-361

26. Aldouri MA, Ruggier R, Epstein O, Prentice HG (1990) Adoptive transfer of hyperthyroidism and autoimmune thyroiditis following allogeneic bone marrow transplantation for chronic myeloid leukemia. Br J Haematol 74: 118-119

27. Like AA, Weringer EJ, Holdash A, MacGill P, Atkinson D, Rossini AA (1985) Adoptive transfer of auto-immune diabetes mellitus in biobreeding/Worcester (BB/W) imbred and hybrid rats. J Immunol 134: 1583-1587

28. Wicker LS, Miller BJ, Mullen Y (1986) Transfer of autoimmune diabetes mellitus with splenocytes from non obese diabetic (NOD) mice. Diabetes 35:855-860

29. Serreze DV, Leiter EH, Shultz LD (1990) Transplantation analysis of $B$ cell destruction in (NOD $\times$ CBA) F1 mouse bone marrow chimeras. Diabetologia 33: 84-92

30. McKeever U, Mordes JP, Greiner DL et al. (1990) Adoptive transfer of autoimmune diabetes and thyroiditis to athymic rats. Proc Nat Acad Sci USA 87: 7618-7622
31. Riley WJ, MacLaren NK, Krischer J et al. (1990) A prospective study of the development of diabetes in relatives of patients with insulin-dependent diabetes. N Engl J Med 323:1167-1172

32. Bleich D, Jackson RA, Soeldner JS, Eisenbarth GS (1990) Analysis of metabolic progression to type 1 diabetes in ICA + relatives of patients with type 1 diabetes. Diabetes Care 13:111-118

33. Atkmsan K, Hansen J, Storb R et al. (1982) T cell subpopulation identified by monoclonal antibodies after human marrow transplantation. I Helper-inducer and cytotoxic-suppressor subsets. Blood 59: 1292-1298

34. Warren HS, Atkinson K, Pernbrey RG, Biggs JC (1983) Human bone marrow allografts: production of and responsiveness to interleukin 2. J Immunol 131: 1771-1774

35. Charmot D, Ragueneau M, Olive D, Maraninchi D, Mawas C (1987) Generation of CD8 cytolytic T cells early after autologous or allogeneic bone marrow transplantation. Bone Marrow Transplant: $183-194$

36. Tarn AC, Thomas JM, Dean BM et al. (1988) Predicting insulindependent diabetes. Lancet I: $845-850$

37. Sibley RK, Sutherland DER, Goetz F, Michael AF (1985) Recurrent diabetes mellitus in the pancreas iso- and allograft. Lab Invest 53:132-146

Received: 2 November 1992

and in revised form: 15 February 1993

Dr. B. Vialettes

Hôpital La Timone

F-13385 Marseille cédex 5

France 